\section{Publication of New Species}

ONE of the inevitable results of the War is a reduction in the output of pure scientific literature. This enforced breathing-space seems an excellent opportunity for scientific workers in general, but systematic zoologists in particular, to assail the problem of the scattering of the literature. co-operation on a small scale between editors in any one country might lay the foundation for more ambitious and far-reaching schemes.

A little judicious exchange would eliminate those cases of journals printing, for example, one helminthological paper a year, and render impossible specific zoological descriptions of new species appearing exclusively, for example, in Arch. Experimental

\begin{tabular}{|c|c|c|c|c|c|c|c|c|c|c|}
\hline In year 1935 & $\begin{array}{l}\text { Number } \\
\text { of pub- } \\
\text { lications } \\
\text { other } \\
\text { than } \\
\text { books }\end{array}$ & $\begin{array}{c}\text { Number } \\
\text { of journals } \\
\text { used }\end{array}$ & $\begin{array}{l}\text { Number } \\
\text { of } \\
\text { authors }\end{array}$ & $\begin{array}{c}\text { Authors } \\
\text { publishing } \\
\text { single } \\
\text { paper } \\
\text { during } \\
\text { the year }\end{array}$ & $\begin{array}{c}\text { Authors } \\
\text { who pub- } \\
\text { lish more } \\
\text { than one } \\
\text { paper and } \\
\text { conflne } \\
\text { publication } \\
\text { to one } \\
\text { journal only }\end{array}$ & \begin{tabular}{|c|} 
Journals \\
publishing \\
one paper \\
only de- \\
voted to \\
the one \\
group of \\
animals in \\
question
\end{tabular} & $\begin{array}{c}\text { Journals } \\
\text { entirely } \\
\text { devoted } \\
\text { to one } \\
\text { group in } \\
\text { question }\end{array}$ & $\begin{array}{l}\text { Number } \\
\text { of new } \\
\text { species } \\
\text { described } \\
\text { in the } \\
\text { year }\end{array}$ & $\begin{array}{c}\text { Number of } \\
\text { journals in } \\
\text { which these } \\
\text { new species } \\
\text { are } \\
\text { described }\end{array}$ & $\begin{array}{c}\text { New species } \\
\text { described in } \\
\text { purely medical } \\
\text { journals }\end{array}$ \\
\hline Protozoa* & 940 & 263 & 605 & 441 & 48 & 150 & 3 & 549 & 83. & 9 \\
\hline Mollusca & 1117 & 376 & 698 & 528 & 56 & 184 & 7 & 1437 & 139 & $\begin{array}{l}\text { Not checked; } \\
\text { probably none }\end{array}$ \\
\hline $\begin{array}{l}\text { Helminths } \\
\text { (including medi- } \\
\text { cal literature) }\end{array}$ & $\begin{array}{c}1400 \\
(392 \\
\text { medical })\end{array}$ & $\begin{array}{c}451 \\
(166 \\
\text { medical) }\end{array}$ & 1191 & 1037 & 55 & 287 & 3 & 776 & 112 & 34 \\
\hline $\begin{array}{l}\text { Siphonaptera } \\
\text { (Insecta) }\end{array}$ & 19 & 17 & 15 & 14 & 1 & 15 & 0 & 15 & 5 & 1 \\
\hline Aves & 1662 & 388 & 1043 & 769 & 93 & 203 & 39 & $230 \dagger$ & 39 & $\begin{array}{l}\text { Not checked ; } \\
\text { probably none }\end{array}$ \\
\hline
\end{tabular}

* These groups are not comparable as entities, and include fossil species.

$\uparrow$ Sub-species as well as species.

Probably only systematists are aware of the extent of this scattering. The output is considerable (Salt points out that 10,000 new species of insects are described every year), but nevertheless a disproportionate amount of time is spent 'grubbing' in the library. Who has not groaned over obscure periodicals, such as the Acta Univ. Latv., the Est. de Sci. Habana or the perennial Igakkai Zasshi?

The table above shows an analysis of the literature of a twelve-months' period chosen at random, and relating to five groups of animals, also chosen at random. No comment is really necessary, but one or two points may be emphasized :

(a) The number of journals which, during the year, print only a single paper dealing with any one of the groups in question;

(b) The low، percentage (20 per cent) of authors publishing more than one paper during the year, who confine these to one journal ;

(c) The scattering of descriptions of 776 new species of helminths through 112 journals.

The causes of this literary diaspora are diverse and numerous. Authors, for example, may desire to publish several papers simultaneously, or obtain plates to illustrate them all, or to increase the circle of their readers, or to achieve priority by rapid publication in some modest journal without a waiting list. Financial considerations, on the other hand, prohibit the production of many journals devoted to single groups, except in cases of special popularity, such as we find in the class Aves. Institutes which publish their own journals must include widely divergent contributions. Editors, with an eye to the standard of their publication, its circulation and limited resources, look upon short papers with favour and encourage 'variety'. There are also geographical, nationalistic and linguistic groupings. Nevertheless, however diverse the legitimate and non-legitimate reasons for the scattering may be, the fundamental underlying cause is the total lack of any real system associated with the publication of scientific literature.

Perhaps it is over-sanguine to dream of international co-operation at the present moment, but even
Medicine. For institutions, a more widespread application of the system of publication of the American Museum might also be advocated.

We hear much from politicians on the subject of post-war reconstruction. Surely the systematic zoologists will seize this unequalled opportunity for turning the present loss of time into future gain?

Ashton Wold, Miriam Rothschild.

Peterborough.

\section{Decipherment of Charred Documents}

THE large number of hand-written documents, such as deeds, accounts and ledgers, which have recently been damaged or destroyed by fire has inevitably directed attention to methods of deciphering charred documents, and the description of a simple photographic method recently found successful in these laboratories may be of interest. The documents on which most of our experiments have been carried out were burnt completely black, but were fairly resistant to handling and showed traces of the writing in relief on the surface. No results were obtained by ordinary photographic copying methods with oblique lighting, with infra-red or ultra-violet radiations, or by the chloral hydrate method described by Messrs. Taylor and Walls of the Metropolitan Police Laboratory at Hendon'.

The method depends on exaggerating photographically the difference between the specular reflectivity of the remains of the plain paper and of the ink. Essentially, the charred paper surface can be regarded as a mirror the surface of which can be made to reflect an intense source of light close to the camera lens and on which the original writing stands out as a dark shadow, presumably due to the disturbance of the paper fibres by the pen and to the presence of some residual salts from the ink. This shadow is photographed by the use of a high contrast blue-sensitive plate such as the Kodak $B \mathbf{5}$. 